\title{
Supplementary Information (S1)
}

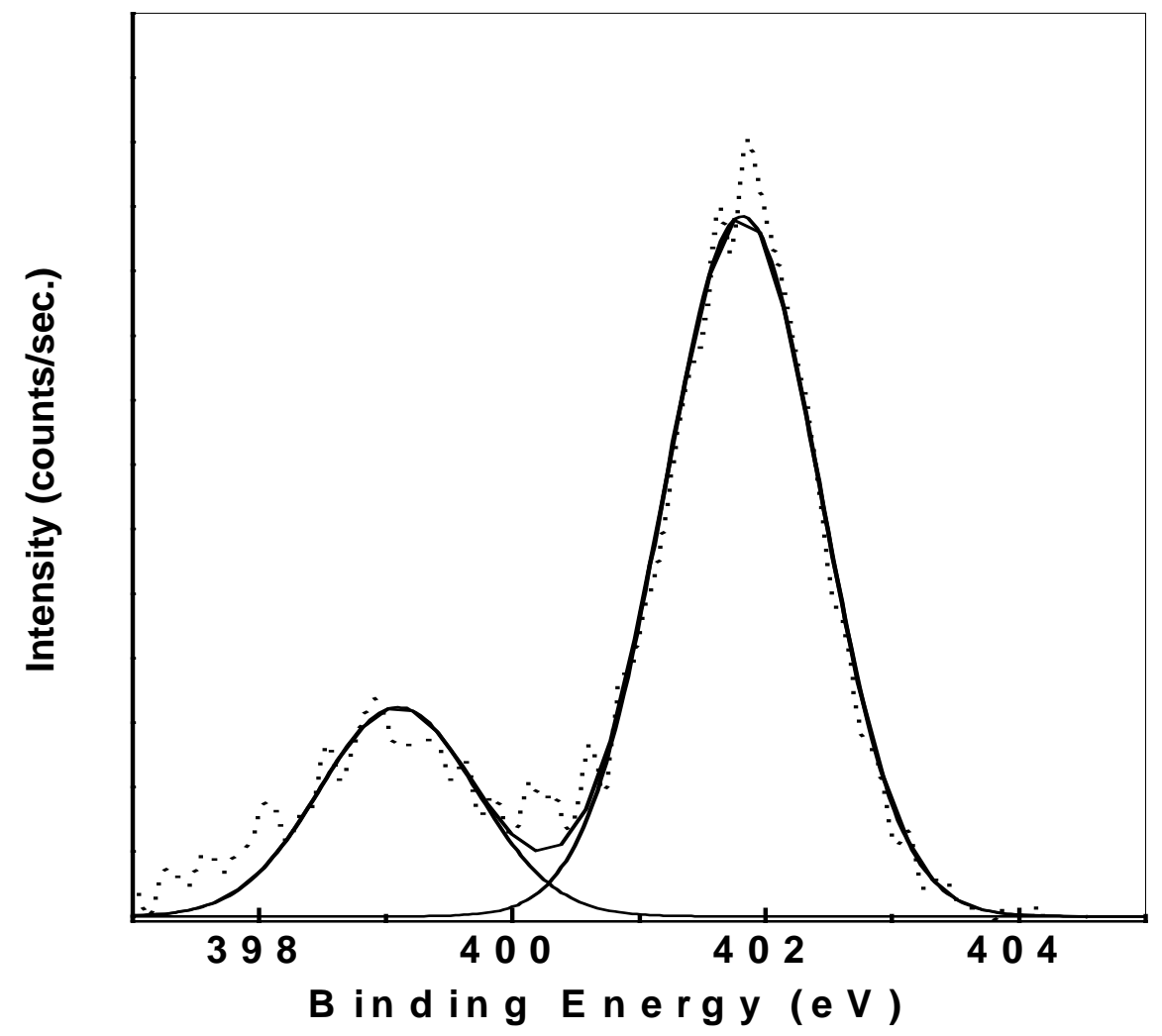

Supplementary information (S1) : $\mathrm{N}$ 1s core level spectra recorded from a porous gold nanoparticle film deposited on copper substrate. 